\title{
Management of the oral manifestations of HIV/AIDS by traditional healers and care givers
}

\author{
MJ Rudolph, BDS, MPH \\ Division of Public Oral Health, School of Oral Health Sciences, University of the Witwatersrand \\ EO Ogunbodede, BChD, MPH, DDPH RCS \\ Division of Public Oral Health, School of Oral Health Sciences, University of the Witwatersrand \\ M Mistry, MSc; BSc \\ Division of Public Oral Health, School of Oral Health Sciences, University of the Witwatersrand
}

\section{Keywords:}

Traditional healers, oral lesions, HIV, AIDS, oral health

\section{Correspondence address:}

Professor M.J. Rudolph

Division of Public Oral Health

Medical School, Room 10Q20

University of the Witwatersrand

7, York Road, Park town 2193

South Africa

Tel: (011) 717-2593/4

Fax: (011)717-2625

Email: rudolphmj@sph.wits.ac.za

\section{Abstract: Curationis 30(1): 56-61}

In many communities of South Africa, traditional healers are often the only means of health care delivery available. The level of knowledge and ability to recognize oral lesions of 32 traditional healers and 17 care-givers were assessed after a two-day workshop. The data collection instrument was a structured questionnaire, complimented by enlarged clinical photographs of the common oral manifestations of HIV/AIDS. Prior to the workshop, $46(93.9 \%)$ of the 49 respondents had never had any formal information on oral health and $43(87.8 \%)$ were unfamiliar with the symptoms of oral diseases. Thirty-five (71.4\%) recognized bleeding gums from A4-size photographs and $1 /(22.4 \%)$ recognized oral thrush. The recognition of other oral manifestations of HIV/AIDS were; oral hairy leukoplakia (41.0\%), angular cheilitis (43.6\%), herpes virus infection $(56.4 \%)$, oral ulcerations $(56.8 \%)$, and in children, parotid enlargement $(27.3 \%)$, and moluscum contagiosum (56.8\%). Traditional healers and caregivers constitute an untapped resource with enormous potential. A positive bridge should be built to link traditional healing with modern medicine in the struggle against HIV/AIDS.

\begin{abstract}
Abstrak
Tradisionele genesers is gewoonlik die enigste gesondheidsverskaffers in baie Suid Afrikaanse gemeenskappe. Die gehalte van kennis en vermoe om orale wonde te erken was gedurende $\mathrm{n} 2$ dae berraad van 32 tradisionele genesers en 17 versorgers ondersoek. Die dataversamelingsinstrument was n gestruktureerde vraestel, geklomplimenteer deur vergrote kliniese fotograwe van gewone orale manifestasies in HIV/VIGS. Voormalige statistieke het gewys dat $46(93.9 \%)$ van dic 49 deelnemers het geen formele inligting oor orale gesondheid bekom nie, en die simptome van orale siektes was onbekend tussen $43(87.3 \%$ ) van die deelnemers. $35(71.4 \%)$ kon bloeiende tandvleis erken deur die gebruik van A4-groottee fotograwe en 11 (22.4\%) kon mondsproci erken. Dic erkenning van ander orale manifestasics was soos gevolg: orale harige leukoplakie (41\%), angulcrc cheilitis (43.6\%), herpesvirusinfeksie (56.4\%) en mondsere $(56.8 \%)$ en in kinders, parotiede vergroting $(27.3 \%)$ and moluscum contiagiosum $(56.8 \%)$. Tradisionele genesers en versorges is dus ook ' $n$ enorme enbekende potensiaal. ' $n$ Positive verband moet dus tussen tradisionele en moderne geneeskunde gebring word in die stryd teen HIV/VIGS.
\end{abstract}




\section{Introduction}

The WHO has delineated a working definition of traditional medicine as "including diverse health practices, approaches, knowledge and beliefs incorporating plant, animal, and/or mineral based medicines, spiritual therapies, manual techniques and exercises applied singularly or in combination to maintain well-being, as well as to treat, diagnose or prevent illness" (World Health Organisation, 2002). Traditional healers (the practitioners of traditional medicine) are deeply interwoven into the fabric of cultural and spiritual life of a large proportion of South Africans and they are easily accessible in urban, peri-urban and remote areas where other health services are lacking (Dlamini, 2000; Mills, Singh, Wilson, Peters, Onia \& Kanfer, 2006).

They are recognized and acknowledged by the community in which they live and practice as competent health practitioners. Some traditional healers have a multifaceted role, which includes training, leadership and participation in a number of medico-religious functions (Kellerman \& Thindisa, 1998). All over the world, there is growing interest in traditional healers as a resource for health care delivery (Nevin, 2000).

In Zambia, traditional healers played an influential role in the promotion of the healing process in the community (Ndubani \& Hoer, 1999). Many patients seek help concurrently from traditional healers and formal health services. Another study from Zambia found that $68 \%$ of 1000 patients attending a formal centre for HIV counseling and testing had seen a traditional healer (Baggaley, Sulwe, Burnett \& Ndovi, 1996). Studies from Tanzania also indicate that approximately $80 \%$ of HIV patients receive their medical attention from a traditional healer rather than from a hospital or primary health care facility (Editor, 1996).

Ngilisho, Mosha \& Poulsen (1994) interviewed 73 traditional healers and 408 villagers in Tanzania. Sixty per cent of the traditional healers claimed that they treated dental patients with an average of three patients per month. A large variety of local herbs was used and about $40 \%$ of them claimed that they would refer the client to a modern health facility if their treatment did not work. Half of the villagers interviewed had experienced toothache and 60 per cent of those who had experienced toothache within the last two years were treated with local herbs from traditional healers. Relief was obtained for more than six months for 40 per cent of the patients, who sought this service. An additional finding was that the establishment of modern emergency oral care in rural health centres and dispensaries did not influence the villagers' use of the traditional healers. Similar reports have come from other countries in Africa (Oyebola, 1986; Zachariah et al, 2002). In a report from Nigeria, traditional healers were the only means of health care delivery available to over $80 \%$ of the rural population (Oycbola, 1986).

It is important that orthodox and traditional practitioners work closely if the HIV/AIDS pandemic is to be combated. Traditional healers are in close proximity to patients and are respected in their communities. Additionally, HIV/AIDS patients sometimes seek the help of traditional healers because they have no alternative for care. In regions with high prevalence rates, hospitals admit only acute cases of AIDS and patients are thus encouraged to seek traditional help.

Chipfakacha (1997) investigated knowledge, beliefs, practices and experiences of traditional healers in relation to sexually transmitted infections, HIV and AIDS. The author found that the advent of HIV/AIDS and the introduction of home-based care in most African countries have increased the case-load of many traditional healers. Most of the patients who are discharged from hospitals on home-based care usually end up at the traditional healer as relatives seek a second opinion or simply because they disagree with the diagnosis of incurable disease. This exposes traditional healers to HIV/AIDS.

To protect themselves and their clients, traditional healers need the right information on HIV/AIDS. Most traditional healers use their bare hands (ungloved) to apply topical medicine. Many also utilize their mouths to suck blood from their patient's body as part of disease management (Chipfakacha, 1997). Neequaye, Neequaye \& Biggar (1991) examined factors related to the spread of HIV infection, including knowledge about AIDS and found among others that skin piercing, including scarification, was done using unsterile instrument by $39 \%$ of 74 rural traditional healers, many of whom had more than one patient per day. Cooperation between traditional healers and scientific medical personnel is essential for an effective and successful HIV/AIDS prevention and infection control programme.

Traditional healers and home care-givers constitute an untapped resource with enormous potential to help address the HIV/AIDS epidemic. Care-givers in the community counsel the physical, spiritual and mentally ill, engage in regular home visits, give support and love to victims and maintain confidentiality.

An exploratory study by Lewis, Daya \& Rudolph (2004) in Zonkizizwe and Dube in the Gauteng province of South Africa demonstrated that about $50 \%$ of patients who visited healers presented with oral lesions.

The objectives of the present study were; to assess the knowledge and practical ability of traditional healers and caregivers with regard to tooth cleaning, and to evaluate their post-workshop ability to recognize and differentiate between the common oral lesions of HIV/AIDS in adults and children.

\section{Materials and methods}

In an earlier all-inclusive study, Lewis, Mistry, Rudolph, Marambana, Monyatsi, Ramela (2001) interviewed 63 consenting traditional healers and care givers from the townships of Zonkizizwe (close to Alberton and about 40 kilometers from Johannesburg) and Dube in Soweto (about 20 kilometers from the inner city of Johannesburg). All the 63 traditional healers and care givers interviewed by Lewis et al (2004) were invited to a 2-day workshop on oral health in Zonkizizwe. Forty-nine $(77.8 \%)$ volunteered to participate in the study. These consisted of 32 traditional healers and 17 caregivers.

Prior to the study, a focus group discussion was held with four randomly selected respondents. This discussion was designed to obtain the views of the participants on the principle and purpose of having an oral health workshop as well as the format and process of the workshop. A dental assistant who could speak the local language facilitated the discussion. Issues such as venue, dates, duration, topics and confidentiality were 


\begin{tabular}{|l|l|l|l|l|l|}
\hline \multirow{2}{*}{ TREATMENTOFFERED } & \multicolumn{7}{|c|}{ ORAL CONDITION } \\
\cline { 2 - 7 } & $\begin{array}{l}\text { Bleeding gums } \\
\text { No }(\%)\end{array}$ & $\begin{array}{l}\text { Calculus } \\
\text { No }(\%)\end{array}$ & $\begin{array}{l}\text { Oral thrush } \\
\text { No (\%) }\end{array}$ & $\begin{array}{l}\text { Tooth decay } \\
\text { No (\%) }\end{array}$ & $\begin{array}{l}\text { Total } \\
\text { No (\%) }\end{array}$ \\
\hline Muti to rinse & $10(71.4)$ & $14(87.5)$ & $14(93.3)$ & $13(76.5)$ & $51(82.3)$ \\
\hline Refer to clinic & $3(21.4)$ & $2(12.5)$ & $1(6.7)$ & $3(17.6)$ & $9(14.5)$ \\
\hline $\begin{array}{l}\text { Use traditional herbs to } \\
\text { strengthen loose teeth }\end{array}$ & $1(7.14)$ & $0(0.0)$ & $0(0.0)$ & $0(0.0)$ & $1(1.6)$ \\
\hline $\begin{array}{l}\text { Burn some incense to kill the } \\
\text { worm in the tooth }\end{array}$ & $0(0.0)$ & $0(0.0)$ & $0(0.0)$ & $1(5.9)$ & $1(1.6)$ \\
\hline Total & $14(100.0)$ & $16(100.0)$ & $15(100.0)$ & $17(100.0)$ & $62(100.0)$ \\
\hline
\end{tabular}

* The total was more than the number of respondents due to overlap of responses.

raised.

At the beginning of the workshop, the purpose was further explained to the participants. The participants were also informed that a questionnaire would be completed at the end of the workshop. Every effort was made to create an atmosphere of cordiality, understanding, trust, and mutual respect.

The formal workshop presentation included the demonstration of the common oral manifestations of HIV/AIDS using clinical photographs, oral hygiene maintenance and treatment of oral lesions. A discussion was held about the present and potential role of traditional healers in managing oral diseases, particularly those related to HIV/AIDS. The information was presented in Zulu using terminology understood by the traditional healers.

At the end of the workshop, a structured questionnaire using closed and openended questions was administered to all the participants. The questionnaire consisted of demographic details of the respondents, questions on knowledge of oral health, recognition of common oral diseases and recognition of symptoms of HIV/AIDS found in adults and children. Enlarged clinical photographs of the most common oral lesions associated with HIV/AIDS were provided and relevant questions on these were put to the respondents. The competence of participants in the practical aspect of tooth brushing was also evaluated (by $\mathrm{MM}$ ) on a scale of 1 (very poor) to 5 (excellent) with each participant brushing own mouth.
All data was analysed on an IBM compatible micro-computer using the SAS statistical package (Version 8.2). Simple proportion was calculated for all the variables and Chisquare test was used to assess differences. Differences were taken as significant at $\mathrm{p}<0.05$.

\section{Ethical Considerations}

Ethical approval was obtained from the Ethics and Research Committee at the University of Luton (London) at Regent College (South Africa) and the University of the Witwatersrand, Johannesburg. Permission to conduct the research was also obtained from the traditional healers themselves using consent forms.

\section{Results}

Forty-six (93.9\%) of the 49 respondents had never had any formal information on oral health and $43(87.8 \%)$ were unfamiliar with the symptoms of oral diseases. However, the traditional healers indicated that they had been offering some treatment to their clients, mainly giving "muti" for rinsing.(Table 1).

The tooth-brushing ability of most of the respondents was found to be very good. It must be noted however that some reported using glycerine, salt, ash or toilet soaps as teeth cleaning agents. Some also reported using pantyhose or plastic strips to "floss" or clean in-between the teeth. A few also use chewing sticks.

Thirty-five (71.4\%) recognized bleeding gums from A4-size photographs and 11 $(22.4 \%)$ recognized oral thrush. Both conditions were usually treated by the respondents using "muti" as a mouthrinse.

The recognition of lesions based on photographs demonstrating pseudomembranous and erythematous candidiasis, angular cheilitis, oral hairy leukoplakia and herpes in adults was assessed. A similar assessment was conducted for oral lesions associated with HIV/AIDS in children using photographs of oral ulcerations, parotid cnlargement and moluscum contagiosum. The responses indicated that over $40 \%$ gave incorrect answers for all the five lesions commonly seen in adults, (Table 2) and five of the six lesions in children, (Table 3). Herpes virus infection, oral ulceration and moluscum contagiosum were the best recognized with correct responses from about $57 \%$ of the traditional healers and care givers (Table 3).

\section{Discussion}

Of the global estimate of 42 million people living with HIV/AIDS, 29.4 million are from sub-Saharan A frica with 5.2 million living in South Africa (UNAIDS, 2005). South Africa now has the highest number of HIV cases in the world and a prevalence rate of $20.1 \%$ among adults aged 15 to 49 years. Thus, every health worker needs to be utilized fully and effectively in the control and prevention of HIV/AIDS. This requires an integrated, multidisciplinary approach.

A focus group discussion, with randomly 


\begin{tabular}{|l|l|c|c|c|c|c|c|}
\hline \multirow{2}{*}{ S/No } & \multirow{2}{*}{ Oral Manifestation } & \multicolumn{2}{|c|}{ Recognition } \\
\hline & & \multicolumn{2}{|c|}{ Correct } & \multicolumn{2}{|c|}{ Incorrect } & \multicolumn{2}{|c|}{ Total } \\
\cline { 3 - 8 } & & No & $\%$ & No & $\%$ & No & $\%$ \\
\cline { 3 - 8 } & Pseudomembraneous candidiasis & 15 & 38.5 & 24 & 61.5 & 39 & 100.0 \\
\hline 2 & Erythematous candidiasis & 21 & 53.9 & 18 & 46.1 & 39 & 100.0 \\
\hline 3 & Angular cheilitis & 17 & 43.6 & 22 & 56.4 & 39 & 100.0 \\
\hline 4 & Oral hairy leukoplakia & 16 & 41.0 & 23 & 59.0 & 39 & 100.0 \\
\hline 5 & Herpes virus infection & 22 & 56.4 & 17 & 43.6 & 39 & 100.0 \\
\hline
\end{tabular}

Table 3. Recognition of the oral manifestations of HIVIAIDS commonly seen in children

\begin{tabular}{|c|c|c|c|c|c|c|c|}
\hline \multirow{4}{*}{$\begin{array}{l}\text { No } \\
1\end{array}$} & \multirow{4}{*}{$\begin{array}{l}\text { Oral Manifestation } \\
\text { Pseudomembraneous candidiasis }\end{array}$} & \multicolumn{6}{|c|}{ Recognition } \\
\hline & & \multicolumn{2}{|c|}{ Correct } & \multicolumn{2}{|c|}{ Incorrect } & \multicolumn{2}{|c|}{ Total* } \\
\hline & & No & $\%$ & No & $\%$ & No & $\%$ \\
\hline & & 15 & 42.9 & 20 & 57.1 & 35 & 100.0 \\
\hline 2 & Erythematous candidiasis & 22 & 61.1 & 14 & 38.9 & 36 & 100.0 \\
\hline 3 & Angular cheilitis & 15 & 40.5 & 22 & 59.5 & 37 & 100.0 \\
\hline 4 & Oral ulceration & 21 & 56.8 & 16 & 43.2 & 37 & 100.0 \\
\hline 5 & Parotid enlargement & 9 & 27.3 & 24 & 72.7 & 33 & 100.0 \\
\hline \multirow[t]{2}{*}{6} & Moluscum Contagiosum & 21 & 56.8 & 16 & 43.2 & 37 & 100.0 \\
\hline & Total & 103 & 47.9 & 112 & 52.1 & 215 & 100.0 \\
\hline
\end{tabular}

selected participants was utilized in this study to design an acceptable format and process for the workshop. This was considered important because of the widespread suspicion between orthodox and traditional healers (Ogunbodede, 1991). There have also been protests especially by the South African Traditional Healers Organisation (THO) accusing pharmaceutical companies and the media of down-playing the role of traditional healers in the treatment of HIV/ AIDS (Mills et al, 2006).

The current health system in South Africa is based on the Primary Health Care Approach (PHCA). The District Health
System (DHS) is the implementation model of the PHC approach. It has been argued that the interface of traditional and modern health care systems could most likely come about within the PIICA and the DHS (Pretorius, 1999). Until recently, few traditional healers have been involved in primary health care activities. Findings from existing collaborative programmes suggest that healers can be a positive force for community-based prevention (Courtright, Chirambo, Lewallen \& Kanjaloti, 2000). There is also increasing recognition of the role of traditional healers in preventing and controlling HIV/AIDS and other sexually transmitted infections.
Although the findings of this study indicate that some preventive and promotive measures are provided by the traditional healers, it also, importantly, identified gaps in the respondents, recognition of the oral manifestations of HIV/AIDS in both adults and children. In Africa, a number of HIV prevention programmes have involved traditional healers. These programmes have helped them to improve their skills in diagnosing, treating, and counseling clients with HIV/ AIDS and sexually transmitted infections (Green, 1999). However, many orthodox practitioners are still sceptical about traditional healers caring for HIV-infected individuals as they are concerned that 
traditional medicine may be ineffective and that they may disseminate inappropriate health education messages. This fear is also shared by those outside the health profession (Tembo, 1991). However, it must be realized that even orthodox medicine does not have all the answers. Kikwulu and Hiza (1997) in their study found that $60 \%$ of parents who had taken their child to hospital subsequently consulted a traditional healer because of dissatisfaction.

Although the psychotherapeutic care provided by traditional healers could be regarded as safe and acceptable, other methods of treatment, such as sucking blood and extracting teeth, are highly suspect and constitute high-risk HIV activities (Ogunbodede, 1991; Editor, 1996). In this study one of the traditional healers "burnt incense to kill the worms in the tooth". This is based on an agelong myth, and such ineffective remedies abound in current practice of traditional medicine (Baker, Millard, Malatsi, Mkoana, Ngoatwana, Agarawal \& de Valliere, 2006). However, the positive aspects of the contributions of traditional healers need to be harnessed and encouraged while attempts should be made to educate them on infection control, high risk procedures and appropriate referral. It is also essential that they are trained to identify and manage simple oral diseases as they are often the first to be consulted by ailing patients.

Masauso et al. (1999) in Zambia found that the traditional healers had detailed constructs of the physiology and infective processes underlying syphilis, gonorrhea, chancroid and AIDS. The study identified some areas of compatibility between indigenous and biomedical models of sexually transmitted infections. Consequently, a programme was established in which traditional healers received AIDS training and learnt to counsel clients on safer sex behaviour. Similarly, an evaluation of a South African AIDS prevention programme found that a year after training, healers were able to define and describe HIV accurately; describe three or more AIDS symptoms correctly and describe accurately three or more means of HIV transmission and prevention (Leclerc-Madlala, 2002)

Since traditional healers see many clients from all works of life, they can be very powerful educators. They can influence the community, as well as other healers through their professional networks. They understand local belief systems and can explain illness and misfortune in ways with which people are familiar. They usually treat the whole person, not just the diseases and so take into account a person's mental, emotional, spiritual as well as physical well-being.

Traditional healers often see their patients together with other family members and as a result can play important role in family counseling. They need to have access to correct information about oral discases and especially the oral manifestations of IIIV/ AIDS (Green, 2000). They can help to achieve the positive pattern of behaviour, beliefs and values that ultimately helps the community they serve. There is however, the need for wide scale studies on the dissemination of information on HIV/AIDS prevention in South Africa.

During the workshop, the discussion revealed role conflicts amongst the different categories of traditional healers. Thus, the concept of 'role' will be particularly important if traditional healers are to function effectively as part of a larger group of health care workers. To facilitate effective cooperation with traditional healers, Green, (1999) has made the following recommendations: 1) be fair and democratic in selecting healers for training; 2) try to identify and train motivated healers who are respected in their communities; 3 ) do not make membership of a traditional healer association a requirement for participation in HIV/AIDS training; and 4) encourage healers to promote sexual abstinence among youth, and fidelity within marriage among adults.

The 49 traditional healers and care-givers who participated in the present study constitute a high percentage of all the traditional healers in the study area. This suggests a willingness to learn new information and share their knowledge with colleagues and orthodox practitioners. This is in agreement with the finding of Baggaley et al (1996) that some traditional healers request help, from orthodox sources, in managing patients who they suspect may be HIVseropositive, especially for HIV testing.

Periodic workshops and training programmes must be held for traditional healers and care givers, on the oral manifestations of HIV/AIDS. A positive bridge should be built to link traditional healing with modern medicine, especially in the struggle against HIV/AIDS.

\section{References}

BAGGALEY, R;SULWE, J; BURNETT, A \& NDOVI, M 1996. Forging links between the formal and traditional in Zambia. Special report: traditional healers. AIDS Analysis Africa 6(1), 12-3.

BAKER, RD; MILLIARD, FJC; MALATSI, J; MKOANA, L; MGOATWANA, T; AGARAWAL,S\& DE VALLIERE, S 2006. Traditonal healers, treatment delay, performance status and death from TB in rural South Africa. The International Journal of Tuberculosis and Lung Disease. 10(6): 670-676.

CHIPFAKACHA, VG 1997.STD/HIV/ AIDS knowledge, beliefs and practises of traditional healers in Botswana. AIDS Care, 9(4), 417-25.

COURTRIGHT, P; CHIRAMBO, M; LEWALLEN S \& KANJALOTI, S 2000. Collaboration with African traditional healers for the prevention of blindness. Singapore: World Scientific Publishing Co. Pty. Limited.

EDITOR 1996. Traditional healers leam they have a role to play in Tanzania's AIDS-control programme. AIDS Anal Afr. 6(1), 12-3.

GREEN, E 2000. The role of traditional healers, Southern Africa. AIDS Action 46, 2-3.

GREEN, EC 1999. Involving healers. AIDS Action Oct-Dec (46), 3.

\section{KELLERMAN, F \& THINDISA, M 1998.} Oral submission to the parliamentary committee on traditional healers and the health care system. Retrieved February 18,1999 from http://www.sahr.com

KIKWILU, EN \& HIZA, JF 1997. Tooth bud extraction and rubbing of herbs by traditional healers in Tanzania: prevalence, and sociological and environmental factors influencing the practices. International Journal of Paediatric Dentistry, 7(1), 19-24.

LECLERC-MADLALA, S 2002. Traditional medical practitioners AIDS training and support programme. Final 
evaluation report. Durban: AIDS Foundation of South Africa. 38 August

LEWIS, H; MISTRY, M; RUDOLPH, MJ; MARAMBANA, T; MONYATSI, V \& RAMELA, P 2001 Oral health practices of traditional healers In Zonkiziziwe and Dube. Journal of Dental Research 80 (4) 2001: 1363

LEWIS, HA; DAYA, M \& RUDOLPH, MJ 2004 Oral health knowledge and original practices of African traditional healers in Zonkizizwe and Dube, South Africa. South African Dental Journal 59(6):243-246

MASAUSO, NM; ROMANO, K; ANYANGWE, S; WISEMAN, J; MACWAN'GI, M; KENDALL, C \& GREEN, EC 1996. A targeted intervention research on traditional healer perspectives of sexually transmitted illnesses in urban Zambia. Current research. Societes d'Afrique et SIDA (13), 7. July

MILLS, E; SINGH, S; WILSON, K; PETERS, E; ONIA, R \& KANFER, I 2006. The challenges involving traditional healers in HIV/AIDS care. International Journal of STD \& AIDS 17 : 360-363.

NDUBANI, P \& HOER, B 1999. Traditional healers as a source of information and advice for people with sexually transmitted diseases in rural Zambia. Tropical Doctor 29, 36-38.

NEEQUAYE, AR; NEEQUAYE, JE \& BIGGAR, RJ 1991. Factors that could influence the spread of AIDS in Ghana, West Africa: Knowledge of AIDS, sexual behaviour, prostitution, and traditional medical practices. Journal of Acquired Immune Deficiency Syndrome 4(9), 914 919.

NEVIN, T 2000. Sangomas: Bridging the gap between traditional healing and biomedicine. Business Doctor 12-15.

NGILISHO, LA; MOSHA, HJ \& POULSEN, S 1994. The role of traditional healers in the treatment of toothache in Tanga Region, Tanzania. Community Dental Health 11(4), 240-2.

OGUNBODEDE, E 1991. Dental care: the role of traditional healers. World Health Forum 12(4), 443-4.
OYEBOLA, DDO 1986. National medical policies in Nigeria. The professionalisation of African medicine. Manchester: University Press.

PRETORIUS, E 1999. Traditional healers. In: Baron, P. (ed.). South African Health Review 1999. Durban: Health Systems Trust, Chapter 18.

TEMBO, KC 1991. Evaluation of source of messages on AIDS by college students. Malawi Medical Journal 7(3), $117-118$.

UNAIDS 2005. Report on the global HIV/ AIDS epidemic. Geneva: Joint United Nations Programme on HIV/AIDS (UNAIDS). Accessed March 2006 www.aidsconsortium.org.uk/

WORLD HEALTH ORGANISATION 2002. Traditional Medicine Strategy 2002-2005, Document WHO/EDM/TRM/ 2002.1, Geneva: World Health Organisation, p. 7

ZACHARIAH, R; NKHOMA, W; HARRIES, AD; ARENDT, V; CHANTULO, A; SPIELMANN, MP; MBEREKO, MP \& BUHENDWA, L 2002. Health seeking and sexual behaviour in patients with sexually transmitted infections: the importance of traditional healers in Thyolo, Malawi. Sexually Transmitted Infections. 78(2), 127-9. 